\title{
Effect of sericin treatment conditions on dye abilty of cotton fabric
}

\author{
Babita Bhandari*, Saroj S. Jeet Singh and Neelam M. Rose \\ Deptt. of Textile and Apparel Designing, I.C. College of Home Science, CCS Haryana Agricultural University, \\ Hisar-125004 (Haryana), INDIA \\ *Corresponding author. E-mail: babita.bhandari55555@gmail.com
}

Received: July 28, 2017; Revised received: August 3, 2017; Accepted: January 15, 2018

\begin{abstract}
A study was conducted to observe the effect of sericin treatment on dye abilty of cotton fabric using natural dye. Different parameters for sericin treatment were optimized on the basis of maximum percent dye absorption and washing fastness. It was found that $0.5 \%(\mathrm{w} / \mathrm{v})$ sericin in the presence of $4 \%$ crosslinking agent and $1 \%$ catalyst treated at $70^{\circ} \mathrm{C}$ for 45 minutes followed by drying at $70^{\circ} \mathrm{C}$ for 4 minutes and curing at $160^{\circ} \mathrm{C}$ for 2 minutes increased affinity of selected natural dye i.e. manjistha towards cotton fabric. Dye uptake of sericin treated fabric increased from $19.5 \%$ to $31.7 \%$ after application of sericin using all the optimized variables.
\end{abstract}

Keywords: Cotton, Dye absorption, Optimization, Parameters, Sericin treatment

\section{INTRODUCTION}

Approximately 80,000 tons of synthetic dyes are used in various industries including textile industry. About $60 \%$ of which are consumed by textile industry alone. The effluent discharged from synthetic dyeing industry hinders photosynthetic process in water sources due to the high TDS (Total dissolved solids), BOD (Biological Oxygen Demand) and COD (Chemical Oxygen Demand) of the effluent and presence of highly coloured unexhausted dye. Moreover some released chemical are poisonous for aquatic organisms (Elango et al., 2017). Various processes are used in the textile industry like desizing, scouring, bleaching, mercerizing and dyeing etc, among which dyeing process consumes $16 \%$ of total water used. The synthetic dye classes used for cotton are direct, reactive, sulphur, vat and azoic dyes (Wang et al., 2011). Textile industry of India is mainly cotton based and it contributes to $4 \%$ of the country's GDP. India is also one of the largest consumers of cotton accounting for about $60 \%$ of the total consumption of cotton (Anon, 2017). Hence synthetic dyes used for cotton colouration represent an ecological threat.

Nonetheless efforts are being made to revive the use of natural dyes in textile. These dyes are not only user friendly but also biodegradable and biocompatible (Haji, 2010). These are extracted from different parts of plants like flowers, roots, leaves, bark etc. Normally natural dyes are extracted from the roots, stems, leaves, flowers, fruits of various plants, dried bodies of certain insects and minerals (Geelani et al., 2015, Vastrad et al., 2017).
In recent years due to the increasing awareness regarding health and environmental hazards associated with the use of synthetic dyes, interest in natural dyes is increasing (Kululkarni et al., 2011). Cellulosic fibres including cotton develop negative charge in contact with water due to the ionization of hydroxyl and carboxyl groups present in its structure. This negative charge on the fibre surface is responsible for lower affinity of natural dyes towards cotton (Burkinshaw, 2016).

Various metallic mordants like salts of copper, iron, chrome, tin etc have been used to improve dye absorption. However the unexhausted metals in the dye bath cause effluent disposal problem (Samanta and Agarwal, 2009). Therefore focus should always be on enhancing dyeability of cotton without harming the environment. This is only possible by using natural mordants like myrobalan (Srivastava et al., 2015), ecofriendly agents like enzymes (Lakhchaura and Bains, 2013) or biopolymers like chitosan (Sundrarajan et al, 2012) and sericin.

Sericin is a gummy substance surrounding silk fibroin. It is composed of 18 amino acids which have strong polar groups such as hydroxyl, carboxyl and amino groups. Hence sericin can form crosslinks, copolymerize and combinations with other polymers. The biochemical characteristics give sericin important biological properties like biocompatibility, antibacterial activity, antioxidant etc (Aramwit, 2009). Indian production of 1600 tons of silk can be source of about 250-300 tons of sericin per year (Gulrajani, 2005)

Keeping in view the functional properties and availability of sericin, the study was undertaken to optimize 
sericin treatment conditions on cotton fabric and the dye ability of treated fabric was assessed.

\section{MATERIALS AND METHODS}

The bleached cotton fabric suitable for apparel purpose and natural dye manjitsha was procured from local market Hisar, Haryana. Sericin powder was procured from Aurangabad, Maharashtra. Citric acid $\left(\mathrm{C}_{6} \mathrm{H}_{8} \mathrm{O}_{7}\right)$ and sodium hypophosphite $\left(\mathrm{NaPO}_{2} \mathrm{H}_{2}\right)$ were provided by manufacturing company Himedia. Citric acid and sodium hypophosphite were selected because both these chemicals were cheap, easily available and if used in less quantity are considered eco-friendly. Fabric was scoured using 1 percent soap, 3 percent sodium carbonate $\left(\mathrm{Na}_{2} \mathrm{CO}_{3}\right)$ at boiling temperature $\left(100^{\circ} \mathrm{C}\right)$ with material to liquor ratio $1: 40$ for 60 minutes. The parameters of sericin treatment i.e. sericin concentration, treatment temperature, time, $\mathrm{pH}$, material to liquor ratio, concentration of crosslinking agent (citric acid) and catalyst (sodium hypophosphite), drying temperature and time, curing temperature and time were optimized on the basis on maximum dye absorp-

\begin{tabular}{ll}
\hline Parameters & $\begin{array}{l}\text { Selected range of parame- } \\
\text { ters }\end{array}$ \\
\hline Concentration of sericin $(\% \mathrm{w} / \mathrm{v}):$ & $.25,0.50,0.75,1.00$ and \\
& 1.25 \\
Treatment temperature $\left({ }^{\circ} \mathrm{C}\right):$ & $40,50,60,70,80$ and 90 \\
Treatment time (Minutes): & $15,30,45,60,75$ \\
$\mathrm{pH}:$ & $5,6,7,8,9$ \\
Material to liquor ratio $(\mathrm{MLR}):$ & $1: 20,1: 30,1: 40,1: 50,1: 60$ \\
concentration of citric acid $(\% \mathrm{w} / \mathrm{v}):$ & $1,2,3,4,5$ \\
concentration of sodium hypophos- & $0.5,1,1.5,2,2.5$ \\
phite $(\% \mathrm{w} / \mathrm{v}):$ & \\
Drying temperature $\left({ }^{\circ} \mathrm{C}\right):$ & $60,70,80,90,100$ \\
Drying time (minutes): & $2,4,6,8,10$ \\
Curing temperature $\left({ }^{\circ} \mathrm{C}\right):$ & $140,150,160,170,180$ \\
Curing time (minutes): & $1,2,3,4,5$ \\
\hline
\end{tabular}

tion and better wash fastness after dyeing with natural dye. The parameters were optimized from the selected range of parameters as given below.

Sericin treated fabric was dyed with natural dye manjistha and dye absorption and colour strength were compared with that of untreated fabric. Colour strength of dyed fabrics was measured using Macbeth 2020+ reflectance spectrophotometer interfaced with a computer.

\section{RESULTS AND DISCUSSION}

Optimization of sericin concentration: It is evident from Table 1 that dye absorption was found to be maximum at 0.50 percent sericin concentration however further increase in sericin concentration decreased dye absorption. Washing fastness was found maximum at 0.50 and 0.75 percent sericin concentration. Hence 0.50 percent concentration of sericin was selected for final application. The reason for less dye absorption might be the aggregation of sericin molecules at higher concentration which hampered the even dispersal of sericin on fabric surface and thus hindering the crosslinking of sericin molecules with the functional groups of cotton. Study by Zhou et al., 2012 revealed that positive charge was developed on sericin treated fibres which resulted into electrostatic attractions between the anion of the annato dye and the cationic segments of the modified cotton fibers. Optimum sericin concentration was obtained as $0.5-0.6 \%(\mathrm{w} / \mathrm{v})$ and dyeability was improved. Similarly according to Bhattacharya and Shah (2000) have reported that low colour strength at higher concentration of alum was obtained due to the strong bond formation between alum and dye but not with the fabric.

Optimization of treatment temperature: Table 2 exhibited that dye absorption was maximum at $50^{\circ} \mathrm{C}$ i.e. $26.61 \%$. The reason for gradual decrease in dye absorption beyond $50^{\circ} \mathrm{C}$ of treatment temperature might be the temperature sensitive nature of silk sericin. Sericin gets degraded at higher temperature (Gupta et al., 2014) which might have reduced the interaction between sericin molecules and cotton.

Optimization of treatment time: Treatment time plays an important role to facilitate establishment of ester linkages between the carboxyl groups of sericin with hydroxyl group of cotton (Das et al., 2013). It is evident from Table 3 that the highest dye absorption and wash fastness of treated fabric was obtained when sericin treatment was carried out for 45 minutes. This might be due to the reason that the saturation point for absorption of sericin was reached at 45 minutes. Increase in treatment time resulted into heterogeneous surface deposition of sericin particles which were removed during washing the treated fabric prior to dyeing. Results are in accordance to findings of Zhou et al. (2012) that amount of natural dye i.e. annatto adsorbed on cotton greatly increased when modification

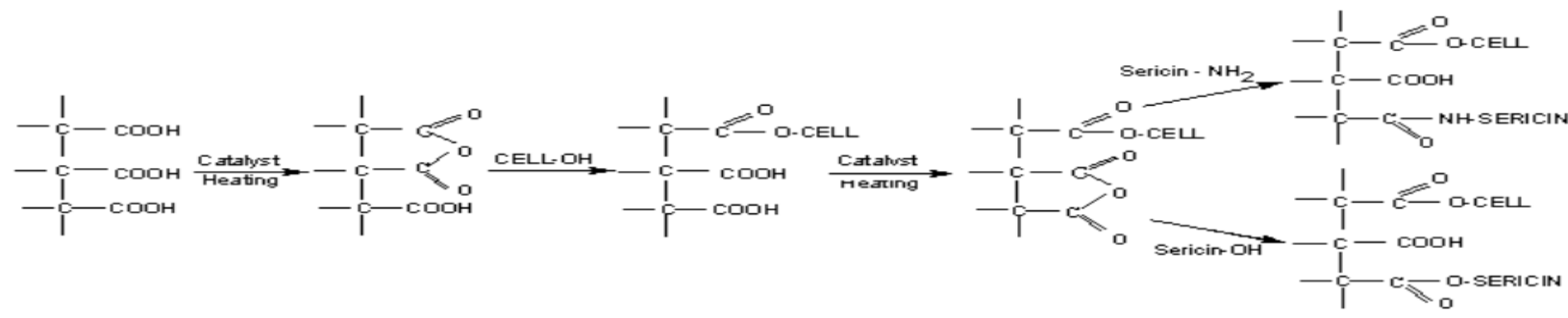

Fig. 1. Reactions among citric acid, cellulose and sericin (Xing et al., 2011). 
Table 1. Effect of sericin concentration on dye absorption and wash fastness.

\begin{tabular}{llll}
\hline $\begin{array}{l}\text { Concentration of } \\
\text { sericin (\%) }\end{array}$ & $\begin{array}{l}\text { Percent dye } \\
\text { absorption }\end{array}$ & \multicolumn{2}{c}{ Wash fastness } \\
\cline { 3 - 4 } \cline { 3 - 4 } & 22.70 & CC & CS \\
\hline 0.25 & 26.55 & 4 & 4 \\
0.50 & 25.63 & 4 & 4 \\
0.75 & 24.37 & $3 / 4$ & 4 \\
1.00 & 24.29 & $3 / 4$ & 4 \\
1.25 & &
\end{tabular}

CC: Colour change; CS: Colour staining

Table 2. Effect of temperature on dye absorption and wash fastness.

\begin{tabular}{llll}
\hline \multirow{2}{*}{$\begin{array}{l}\text { Temperature } \\
\text { C) }\end{array}$} & $\begin{array}{l}\text { Percent dye } \\
\text { Absorption }\end{array}$ & \multicolumn{2}{c}{ Wash fastness } \\
\cline { 3 - 4 } & 22.64 & CC & CS \\
\hline 40 & 26.61 & 4 & 4 \\
50 & 24.02 & 4 & $4 / 5$ \\
60 & 23.07 & 4 & 4 \\
70 & 23.67 & 4 & 4 \\
80 & & 4 \\
\hline
\end{tabular}

$\mathrm{CC}$ : Colour change; CS: Colour staining

Table 3. Effect of time on dye absorption and wash fastness.

\begin{tabular}{llll}
\hline \multirow{2}{*}{$\begin{array}{l}\text { Time } \\
\text { (minutes) }\end{array}$} & $\begin{array}{l}\text { Percent dye } \\
\text { absorption }\end{array}$ & \multicolumn{2}{c}{ Wash fastness } \\
\cline { 3 - 4 } & 22.05 & CC & CS \\
\hline 15 & 26.50 & 4 & 4 \\
30 & 28.72 & 4 & 4 \\
45 & 27.50 & 4 & $4 / 5$ \\
60 & 25.26 & 4 & 4 \\
75 &
\end{tabular}

$\mathrm{CC}$ : Colour change; CS: Colour staining

Table 4. Effect of $\mathrm{pH}$ on dye absorption and wash fastness.

\begin{tabular}{llll}
\hline pH & $\begin{array}{l}\text { Percent dye } \\
\text { absorption }\end{array}$ & \multicolumn{2}{l}{ Wash fastness } \\
\cline { 3 - 4 } & 23.06 & 4 & CS \\
\hline 5 & 25.51 & 4 & 4 \\
6 & 28.67 & 4 & $4 / 5$ \\
7 & 30.02 & 4 & $4 / 5$ \\
8 & 30.83 & 4 & $4 / 5$ \\
9 & & 4 \\
\hline
\end{tabular}

$\mathrm{CC}$ : Colour change; CS: Colour staining

time was less than 60 minutes. Once fixed, sericin started chipping off beyond 60 minutes.

Optimization of treatment pH: Table 4 shows that maximum dye absorption was observed at $\mathrm{pH} 9$ followed by $\mathrm{pH} 8$. Since alkaline $\mathrm{pH}$ causes swelling of cotton fibres which makes them more absorptive towards dye molecules. However at $\mathrm{pH} 9$ uneven and patchy colour was obtained so $\mathrm{pH} 8$ was selected. Moreover there was more attraction between alkali modified cotton and acidic natural dye. Wash fastness was same at pH 6, 7 and 8 which was good for colour change and very good for colour staining.

Optimization of material to liquor ratio: The dye absorption was obtained maximum at 1:30 MLR as indicated in Table 5. The reason for the highest dye
Table 5. Effect of MLR on dye absorption and wash fastness.

\begin{tabular}{llll}
\hline Material to & $\begin{array}{l}\text { Percent dye } \\
\text { liquor ratio (M:L) }\end{array}$ & \multicolumn{2}{c}{ Wash fastness } \\
\cline { 3 - 4 } absorption & CC & CS \\
\hline $1: 20$ & 29.02 & 4 & 4 \\
$1: 30$ & 30.68 & 4 & $4 / 5$ \\
$1: 40$ & 30.31 & 4 & $4 / 5$ \\
$1: 50$ & 29.40 & 4 & $4 / 5$ \\
$1: 60$ & 28.42 & 4 & $4 / 5$ \\
\hline
\end{tabular}

$\mathrm{CC}$ : Colour change; CS: Colour staining

Table 6. Optimization of concentration of citric acid.

\begin{tabular}{llll}
\hline $\begin{array}{l}\text { Concentration of } \\
\text { citric acid (\%) }\end{array}$ & $\begin{array}{l}\text { Percent dye } \\
\text { absorption }\end{array}$ & \multicolumn{2}{l}{ Wash fastness } \\
\cline { 3 - 4 } & 26.02 & $4 / 5$ & CS \\
\hline 1 & 26.79 & 4 & 4 \\
3 & 27.81 & 4 & 4 \\
4 & 31.87 & 4 & $4 / 5$ \\
5 & 28.29 & 4 & 4 \\
\hline
\end{tabular}

$\mathrm{CC}$ : Colour change; CS: Colour staining

Table 7. Optimization of concentration of sodium hypophosphite.

\begin{tabular}{llll}
\hline $\begin{array}{l}\text { Concentration of sodi- } \\
\text { um hypophosphite (\%) }\end{array}$ & $\begin{array}{l}\text { Percent dye } \\
\text { absorption }\end{array}$ & \multicolumn{2}{c}{ Wash fastness } \\
\cline { 3 - 4 } & 28.94 & 4 & CS \\
\hline 0.5 & 31.21 & $4 / 5$ & $4 / 5$ \\
1 & 28.52 & $4 / 5$ & 5 \\
1.5 & 26.65 & $4 / 5$ & $4 / 5$ \\
2 & 26.08 & 4 & $4 / 5$ \\
2.5 & &
\end{tabular}

CC: Colour change; CS: Colour staining

Table 8. Effect of drying temperature on dye absorption and wash fastness.

\begin{tabular}{llll}
\hline Drying & $\begin{array}{l}\text { Percent dye } \\
\text { temperature }\left({ }^{\circ} \mathbf{C}\right)\end{array}$ & \multicolumn{2}{c}{ Wash fastness } \\
\cline { 3 - 4 } & Absorption & CC & CS \\
\hline 60 & 28.27 & 4 & $4 / 5$ \\
70 & 30.67 & $4 / 5$ & 5 \\
80 & 27.64 & 4 & $4 / 5$ \\
90 & 24.50 & 4 & $4 / 5$ \\
100 & 24.44 & 4 & $4 / 5$ \\
\hline
\end{tabular}

$\mathrm{CC}$ : Colour change; $\mathrm{CS}$ : Colour staining

absorption at liquor ratio 1:30 might be that the quantity of liquor was optimum for the absorption of sericin present in solution to the fabric and MLR less than that did not result in uniform absorption of the sericin from the treatment bath. With increase in material to liquor ratio the dilution of sericin increased resulting in less deposition of sericin on the fabrics. Zhou et al. (2012) reported that sericin treatment given to cotton fabric at m:1 ratio of 1:40 had desirable effect on dye absorption and wash fastness.

Optimization of auxiliaries' concentrations: There is less affinity of sericin with cotton in absence of any crosslinking agent (Gupta et al., 2014). In order to increase the fixation of sericin, cotton was treated with crosslinking agent and a catalyst. Maximum dye ab- 
Babita Bhandari et al. / J. Appl. \& Nat. Sci. 10 (1): 102 - 106 (2018)

Table 9. Effect of drying time on dye absorption and wash fastness.

\begin{tabular}{llll}
\hline \multirow{2}{*}{$\begin{array}{l}\text { Drying time } \\
\text { (minutes) }\end{array}$} & $\begin{array}{l}\text { Percent dye } \\
\text { absorption }\end{array}$ & \multicolumn{2}{l}{ Wash fastness } \\
\cline { 3 - 4 } & 28.70 & CC & CS \\
\hline 2 & 30.21 & 4 & $4 / 5$ \\
4 & 27.95 & $4 / 5$ & 5 \\
6 & 26.21 & 4 & 5 \\
8 & 24.07 & 4 & $4 / 5$ \\
10 & & $4 / 5$ \\
\hline
\end{tabular}

CC: Colour change; CS: Colour staining

Table 10. Effect of curing temperature on dye absorption and wash fastness.

\begin{tabular}{llll}
\hline $\begin{array}{l}\text { Curing } \\
\text { temperature }\left({ }^{\circ} \mathbf{C}\right)\end{array}$ & $\begin{array}{l}\text { Percent dye } \\
\text { absorption }\end{array}$ & \multicolumn{2}{c}{ Wash Fastness } \\
\cline { 3 - 4 } & 26.01 & 4 & CS \\
\hline 140 & 28.52 & 4 & 4 \\
150 & 31.53 & $4 / 5$ & 4 \\
160 & 26.37 & 4 & $4 / 5$ \\
170 & 23.70 & 4 & 4 \\
180 &
\end{tabular}

$\mathrm{CC}$ : Colour change; CS: Colour staining

sorption (31.87) was obtained with 4 percent citric acid concentration as shown in Table 6. It is clear from Table 7 that the percent dye absorption using $0.5,1.0$, $1.5,2.0$, and 2.5 percent catalyst were $28.94,31.21$, $28.52,26.65$ and 26.08 respectively with better wash fastness at 1 and 1.5 percent. For further investigation 1 percent concentration of catalyst was selected on the basis of maximum dye absorption and wash fastness. Xing et al. (2011) reported that sericin could be fixed onto the cotton fabric surface by chemical bindings between poly-carboxylic acid, sericin and cellulose. As depicted in figure 1, citric acid gets converted into acid anhydride in the presence of catalyst, further it forms crosslinkage with hydroxyl of cotton and hydroxyl and amide group of sericin.

Optimization of drying temperature and time: For cotton fabric the optimum drying temperature was observed as $70^{\circ} \mathrm{C}$ for 4 minutes optimum time duration for drying as shown in Table 8 and 9. Drying at higher temperature for longer duration might have caused hydrolysis of sericin which made less sericin available for modification leading to the less dye absorption and

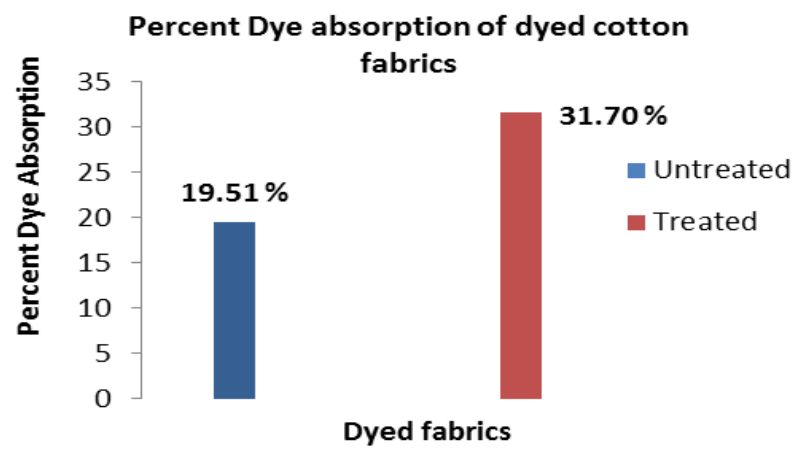

Fig. 2. Percent dye absorption of dyed fabrics.
Table 11. Effect of curing time on dye absorption and wash fastness.

\begin{tabular}{llll}
\hline $\begin{array}{l}\text { Curing time } \\
\text { (minutes) }\end{array}$ & $\begin{array}{l}\text { Percent dye } \\
\text { absorption }\end{array}$ & \multicolumn{2}{c}{ Wash fastness } \\
\cline { 3 - 4 } & 28.53 & CC & CS \\
\hline 1 & 31.67 & $4 / 5$ & 5 \\
2 & 30.53 & $4 / 5$ & 5 \\
3 & 26.79 & 4 & 5 \\
4 & 24.96 & 4 & $4 / 5$ \\
5 & 4 & $4 / 5$ \\
\hline
\end{tabular}

$\mathrm{CC}$ : Colour change; CS: Colour staining

Table 12. Colour obtained and colour strength of dyed fabrics.

\begin{tabular}{l|l}
\hline Samples & K/S \\
\hline Unmodified Dyed fabric & 3.2 \\
Modified Dyed Fabric & $\mathbf{5 . 7}$ \\
\hline
\end{tabular}

poor wash fastness of cotton fabric.

Optimization of curing temperature and time: Curing was done to diffuse the sericin molecules into the fibre polymer system for better affinity. The maximum dye absorption was observed when the treated fabric was cured for 2 minutes at $160^{\circ} \mathrm{C}$ as evident from Table 11 and 12. Curing at higher temperature for longer duration leads to yellowing of the fabric which after dyeing results into undesirable dull colour. Moreover the cotton fabric looses strength at temperature beyond $160^{\circ} \mathrm{C}$. Xing et al. (2011) reported that when the curing temperature was enough, the yellowing of the fabric was serious which could cause severe damage for fabrics.

Dye absorption and colour strength of sericin treated cotton: It is evident from Figure 2 that percent dye absorption of treated dyed fabric was increased from 19.51 to 31.70 . The functional groups present in sericin i.e. $-\mathrm{NH}_{2},-\mathrm{COOH}$, and $-\mathrm{OH}$ enhanced the reactivity of cotton fabric towards natural dye which consequently increased the dye uptake. Similarly the colour strength of the modified dyed fabric was increased from 3.2 to 5.7. In a similar study prior modification of cotton with sericin followed by dyeing of sericin-modified cotton with reactive dyes led to balanced improvements in the properties of the dyed substrates with respect to fixation of reactive dyes, retention of tenacity and colour fastness to light, wash and rubbing (Wang et al., 2006).

\section{Conclusion}

The treatment of cotton with $0.5 \%$ sericin, $4 \%$ citric acid and $1 \%$ sodium hypophosphite followed by drying at $70^{\circ} \mathrm{C}$ for 4 minutes and curing at $160^{\circ} \mathrm{C}$ for 2 minutes gave optimum results in terms of dye absorption and colour strength. Utilization of sericin for cotton treatment will help in reducing water pollution by preventing the use of metallic mordants in dyeing. Exploring other properties of sericin for textile treatment will not only prevent sericin disposal in wastewater but 
also produce textiles with functional properties like antimicrobial and ultraviolet protection properties.

\section{REFERENCES}

Anonymous (2017). Cotton industry of India Available from: https://www.ibef.org/exports/cotton-industry-india.aspx

Aramwit, P., Siritientong T., and Srichana. T. (2012). Potential applications of silk sericin, a natural protein from textile industry by-products. Waste Management and Research, 30(3):217-224.

Bhattacharya, S.D., and Shah, A.K. (2000). Metal ion effect on dyeing of wool fabric with catechu, Journal of the Society Dyers and Colourists, 116, 10-12.

Bhuiyanl, M. A. R., Shaid, A. and Khan, M. A. (2014). Cationization of cotton fiber by Chitosan and its dyeing with reactive dye without salt. Chemicals and Material Engineering, 2(4): 96- 100.

Burkinshaw, S. (2016). Physico-chemical aspects of textile colouration, New York, NY: John Wiley and Sons, Inc. John Wiley and Sons ltd.

Das, D., Bakshi S. and Bhattacharya P. (2014). Dyeing of sericin-modified cotton with reactive dyes. The Journal of The Textile Institute, 105(3):314-320.

Elango, G. (2017). Physico-Chemical Parameters of Textile Dyeing Effluent and Its Impacts with Case study. International Journal of Research in Chemistry and Environment, 7 (1): 17-24.

Gupta, D., Chaudhary, H and Gupta, C. (2014). Sericinbased polyester textile for medical

applications, The Journal of The Textile Institute, DOI: 10.1080/00405000.2014.922244

Gupta, D., Chaudhary, H and Gupta, C. (2015).Sericin based bioactive coating for polyester fabric. Indian Journal of Fibre and Textile Research, 40: 70-80.

Geelani, S. M., Ara, S., Mishra, P., Bhat, S.J.A., Hanifa, S., Haq, S., Jeelani, I., Qazi, G., Sofi, A., Mir, S. A. Khan, P.A., Sarfaraz, W. and Raja, A S.M. (2015). Ecofriendly dyeing of wool and pashmina fabric using Quercus robur L. (fruit cups) dye and Salix alba $L$. (wood extract) mordant. Journal of Applied and Natural Science, 7 (1): $138-143$.

Gulrajani M. L. (2005). Sericin: A bio-molecule of value. Souvenir 20th congress of the International sericulture commission, Banglore, India 15-18th December 2005. Pp. 21-29.
Haji, A. (2010). Functional dyeing of wool with natural dye extracted from Berberis vulgaris wood and Rumex hymenosepolus root as biomordant, Iranian Journal of Chemistry and Chemical Engineering, 29(3): 460-469.

Kulkarni S. S., Bodake U. M. and Pathade G.R. (2011). Extraction of natural dye from chili (Capsicum annum) for textile coloration, Universal Journal of Environment Research and Technology, 1(2): 58-63.

Lakhchaura, P and Bains, S. (2013). A study on dyeing with reactive yellow 15 dye and its effect on modified mulberry silk silk/wool blended fabric. Global Research Analysis, 11(2): 117-118.

Samanta, A. K. and Agarwal, P. (2009). Application of natural dyes on textiles. Indian Journal of Fibre and Textile Research, 34 (4): 384-399.

Srivastava, M., Mogra, D. and Gupta, P. (2015). Dye extraction from Rheum emodi for colouring silk using natural mordants. Journal of Applied and Natural Science. 7 (1): $182-186$.

Sundrarajan, M., Rukmani, A., Gandhi, R. and Vigneshwaran, S. (2012). Ecofriendly modification of cotton using enzyme and chitosan for enhanced dyeability of curcuma longa. Journal of Chemical and Pharmaceutical Research, 4(3):1654-1660

Vastrad, J. V., Walmiki, L. N. and Goudar, G., (2017). Dyeing of cotton yarn with marigold (Tageteserecta) petals: An emphasis on pre-treatments and mordants. Journal of Applied and Natural Science, 9 (2): 1282 - 1286.

Wang, Z., Xue, M., Huang, K., and Liu, Z. (2011). Textile dyeing wastewater treatment: Advances in treating textile, Prof. Peter Hauser (Ed.), ISBN: 978-953-307704-8, InTech, Available from: http:// www.intechopen.com/books/advances-in-treatingtextile-effluent/textile-dyeing

Wang, X., Duan, Y., Tong, Z. and Zhang, Y. (2006). Study on dyeing behaviour of wool fiber modified by sericin. Wool Textile Journal, 10:14-17.

Xing, T., Lie, J., Chen, G., Sheng, J., Sun, D. and Chen, Z. (2011). Study on finishing of cotton fabric by sericin and its properties. Advanced Materials Research, 175176: 624-628.

Zhou, L., Shao, J. Z., Chai, L. Q. and Fu, G. D. (2012). Adsorption behavior of annatto dye on cotton fabrics modified by sericin. Advanced Materials Research, 441:111-115. 